\title{
Reasons for Retirement and the Influence of Retirement on the Life Adjustment amongst Hong Kong Elite Athletes 香港運動員退役的原因及對其生活適應的影響
}

\author{
May Mei DU Eva TSAI \\ Department of Physical Education, \\ Hong Kong Baptist University, HONG KONG
}

杜梅蔡曉偷

香港浸會大學體育學系

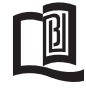

\begin{abstract}
In recent years, there is a growing interest amongst researchers regarding athletes' retirement. While research in this area in western countries is slowly building, research in Hong Kong athletes has gained little attention. The present study examined Hong Kong elite athletes' reasons for retirement and the influence of the retirement reasons on their perception of general life satisfaction and adjustment quality which reflected how well they adapted to their post-retirement life. Analysis of self-administered questionnaires from 75 retired athletes suggested that important reasons for their retirement were difficulties in coordinating sport and study or working demands, and physiological (e.g., injury, age) and financial reasons. Most of them perceived the transition out of sport as a smooth experience. Financial, physiological and burnout (tired of the lifestyle) reasons for retirement were found to be significantly negatively associated with athletes' general life satisfaction. The more they retired due to the three kinds of reasons, the less satisfied they felt toward their current life.
\end{abstract}

\section{摘 要}

近年來對於運動員退役的研究越來越多, 特別是在西方國家, 但是對於香港運動員退役的研究相對較少。本研究調查了香 港精英運動員退役的原因及這些原因對他們適應退役後生活的狀沉及總體生活滿意度的影響。根㨡75份問卷分析發現大多數香港 精英運動員退役是由於難以協調運動訓練與工作或學習的時間, 以及生理和經濟的原因。較多受訪者認為退役轉型的過程較為順 利。研究還發現, 出於經濟原因、生理原因(例如：傷病、年齡) 、和厭倦運動訓練生活而退役, 對於運動員退役後總體生活滿意 度, 有顯著的影響。而出於這三種原因而退役的運動員，對自己的總體生活滿意度則較低。

Keywords: athlete retirement, retirement reasons, adjustment quality, general life satisfaction

\section{Introduction}

In recent years, there has been a growing interest amongst researchers regarding athlete retirement. While some research showed that retirement for athletes is traumatic and negative (Grove, Lavallee, Gordon \& Harvey, 1998; Ogilvie \& Howe, 1986), others have found contrary results. For example, in the studies of Coakley (1983) and Sinclair and Orlick (1993), they found that athletes might even feel relieved from the high demand of competitive sport. So, for some athletes, retirement might be an opportunity for starting a new life.

Much research focused on examining why some athletes were able to adjust better to retirement than others (Chow, 2002; Drawer \& Fuller, 2002; Gordon, 1995; Sinclair \& Orlick, 1993; Taylor \& Ogilvie, 2001; Thomas \& Ermler, 1988). A number of studies found that retirement reasons could have effects on athletes' perceived adjustment quality, that is, how well they were 
able to adapt to their post-retirement life (Gordon, 1995; Sinclair \& Orlick, 1993; Taylor \& Ogilvie, 2001). For example, Taylor and Ogilvie (2001) argued that athletes' free choice to end sports career was the most desirable of reasons for retirement. The decision resides wholly within the control of the athletes. Sinclair \& Orlick (1993) reported that some athletes considered they have achieved their goals in sports, or they felt more time was needed to stay with their family, so they decided to terminate their sports career. These athletes usually perceived better adjustment to post-retirement life. On the contrary, some research studies found that when athletes were forced to retire due to physical injury or declining in performance, they usually experienced more difficult adjustment to postsports retirement life.

This study explored the major factors that lead to Hong Kong elite athletes' retirement and the influence of the factors on their adaptation to post-retirement life and the perception of life satisfaction.

\section{Method}

\section{Participants}

The target population of this study was retired elite athletes in Hong Kong who had previously represented Hong Kong to participate in major international games, such as the Olympic Games, Asian Games, East Asian Games, the Commonwealth Games, and the World Championships. A convenience sampling method was adopted in this study. The questionnaires were sent to retired athletes by mail or in person through the National Sport Associations (NSAs) of Hong Kong.

A total of 182 questionnaires were sent out and 75 completed questionnaires were returned. The response rate was $41.2 \%$. Of the 75 respondents, $42.7 \%(\mathrm{n}=32)$ were female and $57.3 \%(\mathrm{n}=43)$ were male.

The mean length of retirement was 116.86 months (SD $=113.41)$. About $13 \%(\mathrm{n}=10)$ of them had retired for no more than 12 months. The other $87 \%(\mathrm{n}=65)$ had retired more than 12 months, varying from one year to 40 years at the time of the survey.
Their retirement age ranged from 15 to 50 years old. The mean retirement age was $27.18(\mathrm{SD}=5.93)$. About $72 \%$ of them $(n=54)$ retired at the age of 30 years or younger. About $56 \%(\mathrm{n}=42)$ of them were not married and $44 \%(\mathrm{n}=33)$ of the athletes were married at the time of sport retirement. About $89 \%$ ( $\mathrm{n}=$ 67) of them had high school and above education, and $11 \%(\mathrm{n}=8)$ had primary and secondary school education.

About 73\% were full-time athletes. The remaining $27 \%$ of the respondents $(n=17)$ were amateur athletes and had paid jobs before sport retirement. For the fulltime athletes, most of them $(66 \%)$ reported that they started looking for jobs immediately after retirement, whereas the other (34\%) set out looking for jobs later. The mean length before they started job-hunting was 9.44 months (SD = 11.04). Regarding their economic status, about $80 \%$ ( $\mathrm{n}=59)$ considered their current economic status as from average to very high.

About $85 \%$ of the respondents $(n=64)$ were born in Hong Kong, $15 \%$ of them were born in other countries and areas such as Mainland China, and Macao. All of them had represented Hong Kong in competing internationally, 60\% $(\mathrm{n}=45)$ of the athletes won medals for Hong Kong, while 40\% ( $\mathrm{n}=30$ ) didn't win any medals. The athletes had represented Hong Kong competing in 25 different sports.

\section{Instrument}

An Athlete Retirement Questionnaire for Hong Kong was developed by the researcher based on the scales and findings from previous research (Schaefer, 1992; Sinclair \& Orlick, 1993). The questionnaire was designed to have the respondents complete the questionnaires themselves. Apart from personal information, the following three major aspects were measured.

The major factors that lead to athlete retirement were measured in the questionnaire with 15 items using a 5-point Likert Scale ranging from 1 (not important at all) to 5 (extremely important). The fifteen reasons for sport retirement were analyzed using principle components analysis procedure with varimax rotation. From this procedure, seven factors were extracted explaining $65 \%$ of the variance. The factor structure and corresponding items is presented in Table 1. The mean score for each factor was calculated. These factors were used as the basis of subsequent analysis of retirement reasons. 
Table 1. Dimensions of Retirement Reasons.

\begin{tabular}{ll}
\hline Factors & Reason items \\
\hline In-team situation & Fear that further goals won't be achieved \\
& Not very good relationship with teammates \\
& Not very good relationship with the sport organization \\
& De-selection to the national team \\
& Health state \\
Pnjury & Age \\
& Having already reached personal goal \\
& Desire to have more personal time \\
Lack of motivation & Desire to get married/have children \\
& Lack of financial support \\
Financial reasons & Desire to improve economic status \\
& Lack of support from family/friends \\
Individual support & Difficulties in coordinating sport and study/working demands \\
Other role demands & Tired of the life style \\
\hline
\end{tabular}

Perceived adjustment quality was measured with one item by asking the athletes to recall their memory of within one year after retirement to evaluate their selfadjustment at that time. The 5-point Likert Scale was used ranging from 1 (very bad) to 5 (very good). In this study perceived adjustment quality was limited to within one year after retirement because it is a more critical period of time for athletes to recollect their memory about retirement adjustment. General life satisfaction was the athletes' self-evaluation of their current life. It was also measured with one item (are you satisfied with your life now?) using 5-point Likert Scale ranging from 1 (very dissatisfied) to 5 (very satisfied).

\section{Results}

\section{Perceived Adjustment Quality}

The results of the analysis showed no significant mean differences between male and female athletes $(t$ $=.55, \mathrm{df}=71, \mathrm{p}=.59)$, between single and married athletes $(\mathrm{t}=.04, \mathrm{df}=69, \mathrm{p}=.97)$, between those who retired without injury and with injury $(\mathrm{t}=-.23$, df $=71$, $\mathrm{p}=.82$ ) in their perceived adjustment quality (see Table 2). Moreover, there were no significant differences in perceived adjustment quality $(\mathrm{F}=.26$, df $=2, \mathrm{p}=.77)$ amongst the three retirement age groups (15-20, 21-30, 31 and above) (see Table 3).

Table 2. Independent-Samples T Test for Perceived Adjustment Quality in Different Genders, Marital Status, Health State Groups.

\begin{tabular}{lccccc}
\hline Socio-demographic variables & $n$ & $M$ & $S D$ & $t$ & $p$ \\
\hline Gender & 32 & 3.56 & .84 & .55 & .59 \\
Female & 31 & 3.46 & .71 & & \\
Male & & & & & \\
Marital status & 42 & 3.52 & .74 & .04 & .97 \\
Single & 29 & 3.52 & .83 & & \\
Married & & & & & \\
Health state & 15 & 3.47 & 1.06 & -.23 & .82 \\
Without injury & 58 & 3.52 & .68 & & \\
With injury & & & &
\end{tabular}


Table 3. One-way ANOVA of Perceived Adjustment Quality in Three Age Groups.

\begin{tabular}{lllll}
\hline Age groups & $S S$ & $M S$ & $F$ & $p$ \\
\hline Between group & .32 & .16 & .26 & .77 \\
Within groups & 41.93 & .60 & & \\
Total & 42.25 & & & \\
\hline
\end{tabular}

\section{Current General Life Satisfaction}

The current findings showed that athletes retired without injury tended to perceive higher general life satisfaction than those who retired with injury $(t=2.19$, $\mathrm{df}=73, \mathrm{p}<.05$ ) (see Table 4). However, no significant difference in current general life satisfaction was found between male and female athletes $(\mathrm{t}=.23$, $\mathrm{df}=73$, $\mathrm{p}$ $=.82)$, or between single and married athletes $(\mathrm{t}=-1.17$, $\mathrm{df}=71, \mathrm{p}=.25)$. And no significant differences in general life satisfaction was found among the three age groups of the retired athletes $(\mathrm{F}=.14, \mathrm{df}=2, \mathrm{p}=.87$ ) (see Table 5).

Table 4. Independent-Samples $T$ Test for Current General Life Satisfaction in Different Genders, Marital Status, Health State Groups.

\begin{tabular}{llllll}
\hline Socio-demographic variables & $\mathrm{n}$ & $\mathrm{M}$ & SD & $t$ & $p$ \\
\hline Gender & 32 & 3.28 & .85 & .23 & .82 \\
Female & 43 & 3.23 & .97 & & \\
Male & & & & & \\
Marital status & 42 & 3.17 & .91 & -1.17 & .25 \\
Single & 31 & 3.42 & .92 & & \\
Married & & & & & \\
Health state & 16 & 3.69 & .95 & 2.19 & $.03 *$ \\
$\quad$ Without injury & 59 & 3.14 & .88 & & \\
With injury & & & & & \\
\hline
\end{tabular}

* Significant level $\mathrm{p}<.05$

Table 5. One-way ANOVA of Current General Life Satisfaction in Three Age Groups.

\begin{tabular}{lllll}
\hline Age groups & SS & $M S$ & $F$ & $p$ \\
\hline Between group & .24 & .12 & .14 & .87 \\
Within groups & 61.94 & .86 & & \\
Total & 62.18 & & & \\
\hline
\end{tabular}

\section{Dimensions of Retirement Reasons}

By comparing their means of the seven retirement factors, it was found that the "other role demands" $($ mean $=3.57)$, "physiological reasons" $($ mean $=3.49)$ and "financial reasons" (mean $=3.39$ ) were the dominant factors for retirement. Other factors were reported to be less important: "lack of motivation" (mean = 2.61), "burnout" (mean $=2.56$ ), and "in-team situation" (mean $=2.38)$, "individual support" $($ mean $=2.37)($ see Table 6$)$.

Table 6. Descriptive Statistics of Dimensions of Retirement Reasons.

\begin{tabular}{lll}
\hline & Mean & $S D$ \\
\hline other role demands & 3.57 & 1.22 \\
physiological reasons & 3.49 & 1.05 \\
financial reasons & 3.39 & 1.14 \\
lack of motivation & 2.61 & .99 \\
burnout & 2.56 & 1.27 \\
in-team situation & 2.38 & 1.02 \\
individual support & 2.37 & 1.18 \\
\hline
\end{tabular}




\section{Relationship between Retirement Reasons and Perceived Adjustment Quality}

No significant correlation was found between the retirement factors and athletes' perceived adjustment quality (see Table 7). That is, athletes' perception of adjustment quality was not associated with each of the retirement factors respectively.

Table 7. Pearson Correlation Analyses between Retirement Factors and Perceived Adjustment Quality.

\begin{tabular}{lll}
\hline Reason factor & $\begin{array}{l}\text { Pearson Correlation with } \\
\text { perceived adjustment quality }\end{array}$ & $\mathrm{p}$ \\
\hline Physiological reasons & .06 & .62 \\
Individual support & .05 & .68 \\
Financial reasons & .02 & .85 \\
Other role demands & -.16 & .25 \\
Lack of motivation & .03 & .77 \\
In-team situation & -.20 & .09 \\
burnout & .07 & .59 \\
\hline
\end{tabular}

\section{Relationship between Retirement Reasons and Current General Life Satisfaction}

The findings indicated significant negative correlation between "physiological reasons" (e.g. injury, age) and general life satisfaction $(r=-.23, p<.05)$, between "financial reasons" (e.g. lack of financial support) and general life satisfaction ( $\mathrm{r}=-.42, \mathrm{p}<.05)$, and between "burnout" (tired of the lifestyle of being an elite athlete) and general life satisfaction $(\mathrm{r}=-.24, \mathrm{p}<.05)$. That is, the more important physiological, financial reasons and burnout were perceived as retirement reasons, the lower level athletes' current general life satisfaction would be. However, no significant correlation was found between "other role demands" and general life satisfaction $(r=.04, p=.75)$, between "lack of motivation" and general life satisfaction $(\mathrm{r}=-.01, \mathrm{p}=.97)$, and between "individual support" and general life satisfaction $(r=-.16, p=.16)$.

\section{Discussion}

\section{The Dimensions of Retirement Reasons}

The results from this study support previous research and theories on the reasons for retirement. The findings suggested that the Hong Kong athletes in this study retired from elite sport predominantly because of other role demands (difficulties in coordinating sport and work, study demands), physiological reasons (e.g., age, injury), and financial reasons. These reasons are consistent with results from previous studies on athlete career termination (Chow, 2001; Kerr \& Dacyshyn, 2000; Schaefer, 1992; Sinclair \& Orlick, 1993).
The factor "other role demands" such as difficulties in coordinating sport and study and/or working demands was reported as an important cause of retirement. Possibly it is because in Hong Kong many elite athletes also need to engage in other full-time or part-time jobs to earn their living because the grant support from the government could hardly sustain their life. Some athletes are full-time students who had to cope with heavy workload in school. These elite-amateur athletes need to work or study, and at the same time, commit to intensive training and competition schedules. When the athletes feel difficult in coping with the demands, they may choose to terminate their sport career.

The factor "physiological reasons" appeared to be another important factor, which coincided with the common findings of other studies that age and physical injury contributed to sport retirement (Chow, 2001; Drawer \& Fuller, 2002; Kerr \& Dacyshyn, 2000; Lavallee, Grove \& Gordon, 1997; Werthner \& Orlick, 1986). It's known that age is a key criteria for retirement from work. Therefore, it appears that aging is a common factor that leads to both sport retirement and general work retirement. Apart from aging, health status is another important cause to retirement, especially in sports which have very high demands for athletes' physical status.

Although Financial reasons was also an important factor that lead to athletes' retirement in Hong Kong, it was not an important factoring other countries (Shou \& Yu, 2005; Lavallee et al., 1997; Sinclair \& Orlick, 1993; Werthner \& Orlick, 1986). The reason behind may 
be those studies were conducted in China, Australia and Canada, where the governments offered a lot of support to competitive sports development, therefore their elite athletes didn't worry about the financial problem. Whereas in Hong Kong, where the government didn't attach so much importance to elite sports development and didn't offer sufficient financial support to the elite athletes, so financial concerns became an important reason to athlete retirement.

The other four factors lack of motivation, burnout, in-team situation, and individual support were also found in other previous studies (Kerr \& Dacyshyn, 2000; Lavallee et al., 1997; Schaefer, 1992; Swain, 1991), whereas might not have the same contributions among all the retirement reasons. In this study, lack of support from family and/or friends (individual support) and inteam situation (e.g., relationships with teammates, sport organizations) were not important reasons for retirement. Possibly the athletes felt they had received sufficient support from their family and friends, so that they didn't contribute their retirement to lack of individual support. Similarly, the athletes might be able to maintain good relationships with their team-mates and with their organization. Therefore competition within the team was not furious.

\section{The Influence of Retirement Reasons on Athletes' Perceived Adjustment Quality and General Life Satisfaction}

Athletes' retirement reasons appeared to have no significant associations with their perceived adjustment quality. Possibly, this is because other factors might be more crucial to athletes' adjustment to civilian life, such as social support and athletes' ability in coping with sports retirement.

The athletes' general life satisfaction was found negatively influenced by their financial status, age, whether they had injury or not upon retirement and feeling of being tired of the athlete lifestyle. A lot of researchers have reported that if athletes pressured for financial reasons and/or physical health or injury problems to quit competitive sport, they would have a harder transition period (Chow, 2001; Kerr \& Dacyshyn, 2000; Werther \& Orlick, 1986). In particular, financial reasons for retirement appeared to be a good predicator of adjustment quality. The more athletes retired for financial reasons, the more likely they would perceive difficulty in adjustment after their retirement.

\section{Conclusion}

The study indicates that most elite athletes decided to retire due to difficulties in coordinating sport and work and study demands, age, physical injury, lack of financial resources, or desire in improving economic status.

With increased understanding in the important reasons for athlete retirement, the government and related sport organizations can take relevant measures to retain capable athletes. So that elite athletes will stay securely and longer in sport to contribute more to the sport development of Hong Kong.

The present study indicates that no matter what caused the retirement of Hong Kong elite athletes, it does not seem to affect their life adjustment. However, athletes who retired mainly due to financial reasons, physiological reasons (e.g., age, injury) and burnout (tired of the lifestyle) reasons tended to felt less satisfied with their current life. The knowledge of these factors will benefit related persons and organizations to assist retired athletes to adapt to post sports life.

As convenient sampling method was used and the recall of the retirement experience, a limitation exists that may reduce the generalizability of the study. Some of the athletes assessed in this study had been retired for a long period of time at the time of data collection. Therefore, it may be desirable to control for the time factor. In future studies, it will be useful to examine whether perceptions of life adjustment quality change as a function of time.

\section{References}

Chow, B. C. (2001). Moving on? Elite Hong Kong female athletes and retirement from competitive sport. Women in Sport and Physical Activity Journal, 10(2), 47-81.

Chow, B. C. (2002). Support for elite athletes retiring from sports: The case in Hong Kong. Journal of The International Council for Health, Physical Education, Recreation, Sport and Dance, 38(1), 3641.

Coakley, J. J. (1983). Leaving competitive sport: Retirement or rebirth? Quest, 35, 1-11. 
Drawer, S., \& Fuller, C. W. (2002). Perceptions of retired professional soccer players about the provision of support services before and after retirement. British Journal of Sports Medicine, 36(1), 33-38.

Gordon, S. (1995). Career transitions in competitive sport. In T. Morris \& J. Summers (Eds.), Sport psychology: Theory, applications and issues (pp. 474-501). Brisbane: Jacaranda Wiley.

Grove, J. R., Lavallee, D., Gordon, S., \& Harvey, J. H. (1998). Account-making: A model for understanding and resolving distressful reactions to retirement from sport. Sport Psychologist, 12(1), 52-67.

Kerr, G., \& Dacyshyn, A. (2000). The retirement experiences of elite, female gymnasts. Journal of Applied Sport Psychology, 12, 115-133.

Lavallee, D., Grove, J. R., \& Gordon, S. (1997). The causes of career termination from sport and their relationship to post-retirement adjustment among eliteamateur athletes in australia. Australian Psychologist, 32(2), 131-135.

Ogilvie, B. C., \& Howe, M. (1986). The trauma of termination from athletics. In J. M. Williams (Ed.), Applied sport psychology (pp. 365-382). Palo Alto, CA: Mayfield Pub. Co.

Schaefer, U. (1992). Retirement and adjustment process of top level athletes. Hungarian University for Physical Education and Sport, Bubapest.

Shou, W. J., \& Yu, D. Y. (2005). The inquiry analysis of the reasons why Chinese excellent athletes retired from service so early. Journal of Anhui Sports Science, 26(2), 40-43.

Sinclair, D. A., \& Orlick, T. (1993). Positive transitions from high-performance sport. Sport Psychologist, 7(2), 138-150.

Swain, D. A. (1991). Withdrawal from sport and schlossberg's model of transitions. Sociology of Sport Journal, 8(2), 152-160.
Taylor, J., \& Ogilvie, B. (2001). Career transition among athletes: Is there life after sports? In J. M. Williams (Ed.), Applied sport psychology: Personal growth to peak performance (pp. 480-496). U.S.: Mayfield Publishing Company.

Thomas, C. E., \& Ermer, K. L. (1988). Institutional obligations in the athletic retirement process. Quest, 40(2), 137-150.

Werthner, P., \& Orlick, T. (1986). Retirement experiences of successful Olympic athletes. International Journal of Sport Psychology, 17, 337-363.

\section{Acknowledgments}

The first author would like to extend her sincere thanks to Dr. Eva Tsai, Department of Physical Education, Hong Kong Baptist University (PE Dept., HKBU), who supervised her in completing this study and reviewed this paper for me with Prof. Lena Fung, PE Dept., HKBU. She would also thank Prof. Leung Mee Lee, PE Dept., HKBU, for helping her in distributing and collecting the questionnaires.

\section{Correspondence:}

$\begin{array}{ll}\text { Author: } & \text { DU Mei, May } \\ \text { Affiliation: } & \begin{array}{l}\text { Department of Physical Education, } \\ \text { Hong Kong Baptist University, }\end{array} \\ & \text { Kowloon Tong, HONG KONG } \\ \text { Email: } & \text { maydu@msn.com } \\ \text { Telephone: } & 852-3411-7720\end{array}$

